\title{
From G.E.D. to Ph.D.: Eric Thomas as a Model of Educational Success
}

\author{
Cassandra D. Chaney ${ }^{1,2}$, Nia Nicks ${ }^{1} \&$ Conial Caldwell Jr. ${ }^{1}$ \\ ${ }^{1}$ College of Human Sciences, School of Social Work, Louisiana State University, Baton Rouge, Louisiana, USA \\ ${ }^{2}$ College of Human Sciences, School of Social Work, Child and Family Studies, Louisiana State University, \\ Baton Rouge, Louisiana, USA \\ Correspondence: Cassandra D. Chaney, College of Human Sciences and Education, School of Social Work, \\ Child and Family Studies, Louisiana State University, 2146 Ruffin G. Pleasant Hall, Baton Rouge, LA, \\ 70803-4300, USA. E-mail: cchaney@1su.edu
}

Received: August 28, 2020 Accepted: October 5, 2020 Online Published: November 12, 2020

doi:10.5539/jel.v9n6p42 URL: https://doi.org/10.5539/jel.v9n6p42

\begin{abstract}
Since the General Educational Development (GED) Program was established in 1943, more than 17 million people have received a GED Credential. According to the American Council on Education (ACOE), the GED test is considered an alternative option to the US High school diploma, HiSET and TASC tests; the GED test verifies whether the test taker has the United States or Canadian high school-level academic skills (Larson et al., 2016; Rice, 2016). The GED tests entail five subject contents such as writing skills, reading skills, social studies, science, and mathematics - and although the standards required for passing the tests vary across states, these standards are generally similar (Larson et al., 2016; Rice, 2016). This chapter will examine the words Dr. Eric Thomas uses during an interview on the day that he obtained his Ph.D. (Philosophy in Education) from Michigan State University. During this interview with Glenn Twiddle, Dr. Thomas discusses the various factors that motivated him to pursue and earn a Ph.D. In particular, this content analysis will determine the themes Dr. Thomas believes are essential catalysts for educational success. Qualitative analysis of Dr. Thomas's interview reveals four themes related to (a) The Habit of Avoiding Challenges; (b) The Value of Facing Challenges; (c) The Importance of Receiving Encouragement and Accepting Help; (d) The Fragility of Work-Life Balance. Essentially, these themes highlight Dr. Thomas's initial habit of running from academic challenges, the reasons why he faced educational challenges in his life, what he learned about himself after facing academic challenges, the importance of receiving encouragement and accepting help from others, as well as how he manages work-life balance.
\end{abstract}

Keywords: African-American, black, black student, education, Eric Thomas, G.E.D., graduate school, Ph.D., social supports, support networks

\section{Introduction}

In 1943, the GED Program began; since then over 17 million people have received a GED Credential. According to the American Council on Education (ACOE), the General Educational Development (GED) test is considered an alternative to the US High school diploma, HiSET[1] and TASC[2] tests; the GED test verifies whether the test taker has the United States or Canadian high school-level academic skills (Larson et al., 2016; Rice, 2016). The GED tests consist of five subject content areas-writing skills, reading skills, social studies, science, and mathematics - and although the standards required for passing the tests vary across states, these standards are generally similar (Larson et al., 2016; Rice, 2016). The five tests in the GED battery take approximately 7 hours and 45 minutes to complete. "All of the tests use a multiple-choice testing format, and the writing test has a short essay component. There have been four generations of GED exams: the original GED tests released in 1942, the 1978 series, the 1988 series, and the current series released in January 2002.” (Tyler, 2005, p. 47).

\section{Significance of the Current Topic}

The purpose of this chapter is to examine the words Dr. Eric Thomas uses during an interview on the day that he earned his Ph.D. in Education from Michigan State University (MSU). During his interview with Glenn Twiddle, Dr. Thomas discusses the various factors that motivated him to pursue and earn the Ph.D. (Twiddle, 2015). There are five reasons why we place this accomplished Black male within this scholarly conversation on educational success. First, Dr. Thomas is an African American male, and represents a demographic that 
generally has less educational success than his female counterparts (Kafele, 2012) do. Second, Dr. Thomas transitioned from a general educational diploma (G.E.D.) to a doctorate degree (Ph.D.), which is a rare educational trajectory in academe (Maralani, 2011). Third, Dr. Thomas is a non-traditional student, and as such, faced certain challenges that his traditional student peers did not experience (Chen et al., 2020). Fourth, in addition to discussing the attitude that was key to his educational success, Dr. Thomas discusses how he balances the demanding roles of student, husband, father, son, shepherd, and motivator (Heckman et al., 2011). Finally, Dr. Thomas has used his platform to inspire others as a motivational speaker. Several of his motivational speeches are on YouTube and thousands of people have viewed these speeches. Specifically, "Take Full Responsibility" (136,000 views), "Success Routine" (317,000 views), "It's Your Time" (591,000 views), "Separate Yourself" (1 million views), "Change the Way You See Yourself" (2.1 million views), and "You Owe You" (8.3 million views), are a few of the speeches this dynamic Black male has offered the world.

During World War II, The GED program was initially a military-related credential. Ralph Tyler led an advisory committee to the Army Institute who selected five content tests from the Iowa Test of Educational Development to form the first GED tests in 1942. According to Tyler (2005), "The purpose of the exams was to certify that veterans returning from World War II without a conventional high school diploma had the skills to take advantage of the postsecondary education benefits provided in the GI Bill."[1] (p. 48). Since many enlisted males and females withdrew from school to serve the country before graduating, the tests certified that these individuals had acquired skills within the military that were similar to the cognitive skills possessed and obtained by regular high school graduates. Thus, the GED became a high school "equivalency" certificate, [or, "General Equivalency Diploma"] and many states currently have "equivalency diploma" printed on the GED certificates they issue. The first GED tests were administered to returning veterans in 1943. However, New York became the first state to allow school dropouts who were not veterans to seek the GED credential in 1947. Although other states began to offer the GED, few dropouts requested, sought, or obtained this new credential in the early years. In 1949, 570 GED testing centers across the nation administered the tests to 39,000 individuals.[2] Since that time, the GED has become the "primary second-chance credential for school dropouts" (Tyler, 2005, p. 48).

\section{Review of Literature}

A substantial body of literature has examined various aspects of the GED (Tyler, 2005; Warren et al., 2006). In addition to these works, an increasing number of dissertations have examined some aspect of the GED experience. While some dissertations have focused on the retention of GED students (Grover, 2013), others have examined the social support systems of GED learners (Campbell, 2017), or the transition to college among GED credentialed community college students (Carson, 2017). Even more recent dissertations have explored the completion and retention rates of GED holders (Rice, 2019), or compared student community college success among individuals with a GED, high school diploma, or alternative diploma (Miles, 2020).

\subsection{History of the General Educational Development (GED) Program}

The GED program was a military-related credential that traces to World War II. In 1942, Ralph Tyler headed an advisory committee to the Army Institute who selected five tests from the Iowa Test of Educational Development to form the first GED tests. According to Tyler (2005), "The purpose of the exams was to certify that veterans returning from World War II without a conventional high school diploma had the skills to take advantage of the postsecondary education benefits provided in the GI Bill.” (Note 1) (p. 48). Since many enlisted men and women left school to serve the country before graduating, the tests certified that these individuals had acquired skills in the military that were equivalent to the cognitive skills possessed by regular high school graduates. Thus, the GED became a high school "equivalency" certificate, [or, "General Equivalency Diploma"] and many states currently have "equivalency diploma" printed on the GED certificates they issue. The first GED tests were administered to returning veterans in 1943, however, in 1947 New York became the first state to allow school dropouts who were not veterans to seek the GED credential. Although other states began to offer the GED, few dropouts sought this new credential in the early years. In 1949, 570 GED testing centers across the nation administered the tests to 39,000 individuals (Note 2). Since that time, the GED has become the "primary second-chance credential for school dropouts" (Tyler, 2005, p. 48)).

\subsection{Criticisms of the General Educational Development (GED)}

There are three notable criticisms of the GED. The first criticism is that many individuals may regard the GED as an easier-to-obtain secondary credential and thus may be more inclined to drop out of high school (Heckman et al., 2011). Findings show that the GED may incite potential high school graduates to drop out of school (Heckman et al., 2011; Heckman et al., 2012). Additionally, within one study of high school withdrawals, at least $40 \%$ of individuals endorsed they "thought it would be easier to get a GED" (Quinn, 1997). The second 
criticism is that the GED obscures accurate graduation statistics. In other words, combining high school graduates and GED holders hides declines in traditional high school graduation rates and disguises educational problems (such as incentivizing dropouts). Finally, the practice of improperly counting the GED as a high school diploma generates biased estimates of the returns to education (Heckman et al., 2011). Returns to education referred to at least the four-year college completion.

\section{Educational Trajectories of Black Males}

The successful matriculation of Black males through the educational system is contingent upon their capacity to navigate this system by identifying systems of support. While the educational setting has some risks, Black boys are identified as being the most marginalized group in the public-school setting (Brown et al., 2013; Dancy II, 2014; Dancy \& Brown, 2012; Howard, 2013; Noguera, 2003; Polite \& Davis, 1999).

When compared to girls, boys have been found to have poorer social and academic performance (Lee, 2002; Matthews et al., 2010), poorer relationships with their teachers (Matthews et al., 2010), and are more likely to be referred for special education (Coley, 2001; Matthews et al., 2010; Silverman, 2003). As mentioned, the Black male experience is exacerbated when compared to their counterparts and the adverse effects within the school setting. Black boys are subjected to discriminatory practices and unfair treatment as it has been found that they are often labeled by both their teachers and administrators (Ferguson, 2000; Matthews et al., 2010), which prevents the development of positive relationships in the school setting. It has been found that teachers lower expectations for Black male students (Ferguson, 2000; Matthews et al., 2010), which could negatively affect their academic performance. Prior research has revealed that Black male students show signs of academic complications as early as the $4^{\text {th }}$ grade, which is a response to the negative perceptions that their teachers had toward Black Black male students (Chatterji, 2006; Justice et al., 2005; Matthews et al., 2010). Consequently, not only are Black boys more likely than Black girls to be placed in special education programs, they are also more likely to be referred to and placed in special education than any other group, which decreases their likelihood of receiving a high school diploma (Davis, 2004; Joe \& Davis, 2010; Scott et al., 2013).

\subsection{School-to-Prison Pipeline}

The school to prison pipeline is a form of oppression that systemically forces students, primarily male students of color, out of school and into the juvenile justice system, which ultimately leads to prison (Losen et al., 1972; Meiners \& Winn, 2010; Polite \& Davis, 1999; Winn, 2019). Several factors contribute to Black youth's entry to the school to prison pipeline. For one, labeling and poor student-teacher relationships subject Black males to harsh or over disciplinary actions, which could result in out of school suspension, detention, or complete removal from public-school settings (Marcucci, 2020). Research has found that Black males are suspended at higher rates compared to any other ethnic or racial group within the country (Brown et al., 2013; Dancy II, 2014; Marcucci, 2020; Nance, 2015; Neitzel, 2018). Okonofua and Eberhardt (2015) conducted a study that supports the theory of the "Black escalation effect", where Black students were shown to be subjected to harsh punishment and identified as more troubling than their counterparts after their second infraction. This affects Black males' ability to achieve academic markers, like obtaining a high school diploma, as school absence and the loss of instructional time contribute to low achievement outcomes (Dancy II, 2014).

Another reality that places Black males at risk of the school to prison pipeline is the minimal funding allocated to community or neighborhood schools, which prevent the development of much-needed programs and resources. The funding that neighborhood and community schools receive is wedged by tax dollars, which is oftentimes not enough to fund enhancement or gifted programs (Scott et al., 2013). In fact, cities or urban areas receive $\$ 500$ less per student than what is provided for suburban school districts (Dancy II, 2014; Legters et al., 2004). According to the Schott Report, Black males are least likely to receive a high school diploma after starting high school, but when provided with necessary resources and opportunities, these students have the potential to meet and exceed the performance of their counterparts (Dancy II, 2014; Schott Foundation for Public Education, 2012).

\subsection{From High School to College}

Black male students that find success in the school setting do so while suffering from factors related to their social development. According to (Dubois et al., 2002), cultural socialization is important to the development of Black youth, however, many are ostracized because their academic achievement may be viewed as "acting White" (Matthews et al., 2010). Since Black males may experience being ostracized, lack positive relationships, and are subjected to negative bias from teachers and faculty when pursuing an education, hiring Black male faculty can contribute to the success of Black male students (Fergus, 2009; Joe \& Davis, 2010; Scott et al., 2013; Thompson et al., 2004). The hiring of Black male teachers or faculty offers Black male students' representation, and 
encouragement to continue to work toward academic attainment and future educational pursuits. Not only is the representation and mentorship needed in grade school, but it is also important on the collegiate level, as studies have shown that having Black faculty helps to retain Black students (Dancy, 2011; Strayhorn, 2010). Furthermore, it has been found that Black student engagement increased when their professor was Black, as Black students depend on stable mentorship to better cope and adjust socially while at the collegiate level (Brooms \& Davis, 2017). This is important as Black males that attend predominately-White institutions (PWIs) also face social exclusion among a host of other related stressors that may hinder their ability to successfully matriculate through higher education (Brooms \& Davis, 2017; Jaggers \& Iverson, 2012).

\section{Resilience in Education}

In general, resilience is the ability to bounce back; the term resilience derives from the Latin word resilience meaning to spring back (Masten et al., 2013). Resilience refers to the "dynamic and encompassing positive adaptation within the context of significant adversity" (Luthar et al., 2000, p. 543). Whereas, educational resiliency refers to the students' capability to academically excel despite hardships and risk factors (Bryan, 2005; Calhoun et al., 2019; Wang et al., 1997). Academic success and resilience are defined as a process of obtaining academic success regardless of an individual's statistically 'at-risk' background such as low socioeconomic status and single-parent household (Morales \& Trotman, 2011). According to Wang et al. (1994), academic resilience is "the heightened likelihood of success in school, and other life accomplishments despite environmental adversities brought about by early [adolescent] traits, conditions, and experiences (p. 46)." Therefore, instead of being a trait, academic resilience is "the process and results that are part of the life story of an individual who has been academically successful, despite obstacles" (Morales \& Trotman, 2011, p. 8).

\subsection{Risk and Protective Factors}

Researchers and theorists maintain that resilience contains two concepts: risk factors and protective factors (Masten \& Reed, 2002; Williams \& Portman, 2014). Risk factors are conditions or circumstances that heighten the probability of problems occurring (Greene \& Conrad, 2002). Whereas, protective factors are conditions or circumstances that decrease the likelihood that problems will happen (Morales \& Trotman, 2004). Therefore, although an individual may be at risk for one or more negative outcomes, with the right support, they can overcome a self-defeating attitude, achieve academic success, and demonstrate educational resilience (Martinez-Torteya et al., 2009; Zolkoski et al., 2016).

\subsection{Environmental Factors}

Researchers and theorists found that environmental factors (external factors) influence resilience (Rutter, 2007; Ungar, 2008) and academic resilience (Coley, 2011; Morales \& Trotman, 2011; Trask-Tate \& Cunningham, 2010). Various environmental protective factors promote academic resilience among disadvantaged students. Some of these protective factors include the home environment, family involvement, parental monitoring, family support and expectations, classroom climate, school support, school environments, school and classroom learning environment (i.e., facilities and technology access), teacher-student rapport, caring relations, principals' transformational leadership style, high expectations, extracurricular activity involvement, encouragement for participation in meaningful activities, equality, and resources (Agasisti et al., 2018; Benzies \& Mychasiuk, 2009; Borman \& Overman, 2004; Cunningham \& Swanson, 2010; McMillan \& Reed, 1994; Murray \& Malmgren, 2005; Ruiz, 2002; Thapa et al., 2013; Wang et al., 1997; Waxman et al., 1997; Waxman et al., 2003; Werner, 2012). Hence, educational resilience is a process that can be developed, fostered, and cultivated within the context of a student's school (Newman \& Dantzler, 2015), neighborhood, and community. Thus, environmental risk factors include but are not limited to negative life events, trauma, child abuse or neglect, lack of parental supervision, low teacher expectations, drug accessibility, peer rejection, or race-related stressor (i.e., discrimination; Davenport, 2018; Wang et al., 1997).

\subsection{Individual Factors}

Various individual characteristics (e.g., high levels of self-esteem, sense of worth, and value self-efficacy and motivation) correspond with resiliency among students (Allen, 1992; Wang et al., 1994). Further, Martin and Marsh (2006) developed the 5-c's model which recognized the following individuals' characteristics as resilience factors: confidence (self-efficacy), coordination (planning), control, composure (low anxiety), and commitment (persistence). Additionally, Morales (2010) amended five individual protective factors for skillful mentoring for future academic success: (1) willingness/desire to move up in social class; (2) caring school personnel; (3) caring school personnel; (4) sense of obligation to one's race/ethnicity; and (5) strong future orientation. Additionally, emotional intelligence was identified as a protective factor regarding academic resilience (Ford, 1996). Additionally, cooperation and communication, empathy, strong problem-solving skills, 
well-defined goals and aspirations, high self-efficacy, and self-awareness acted as individual protective factors for academic outcomes (Constantine et al., 1999). Whereas, individual risk factors include academic problems, undiagnosed mental health problems, and childhood victimization (Davenport, 2018).

\subsection{Recommendations for Educational Resilience}

Downey (2008) offered recommendations to foster educational resilience. Downey's (2008) suggestions are centered around bolstering protective factors within four clusters: teacher-student rapport, classroom climate, instructional strategies, and student skills. Recommendations for teacher-student rapport entailed establishing healthy interpersonal relationships, setting and communicating realistic academic performance standards and expectations, and promoting students' strengths as well as boosting students' self-esteem. Recommendations for classroom climate consist of informing students of their responsibility to obtain success, fostering a caring meaningful community, offering opportunities for meaningful participation and collaboration, and setting clear consistent behavioral expectations. Recommendations for instructional strategies pertain to promoting collaborative learning strategies and encouraging students to tutor each other. Similarly, Morrison and colleagues (2007) encouraged collaboration to foster academic resilience. Then, recommendations for student skills include teaching transferable life skills (e.g., social skills, problem-solving skills, assertiveness skills, and critical thinking, literacy skills. Similarly, Morrison and colleagues (2007) suggested educators teach social (competence) and emotional education (including problem-solving and conflict resolution) within the classroom. Also, Morrison and colleagues (2007) offered additional suggestions to promote student resilience such as promoting autonomy, sense of purpose, and achievement motivation. Regarding autonomy, educators should teach students the confidence and capability to work and function independently. Educators can promote a sense of purpose by encouraging students to explore career and post-secondary educational opportunities. Regarding achievement motivation, educators should incentivize and reward students for achievements and contributions.

\section{Theoretical Framework: Phenomenology}

Phenomenology is the study of consciousness as experienced from the first - person point of view (Smith, 2006). This theoretical framework recognizes that words are key to understand how individuals perceive their social worlds. Individuals that study language, or phenomenologists, examine the "structures of consciousness from within" (Moran, 2002, p. 14), or the words "actors" use to get a glimpse into their thoughts, feelings, and behaviors (Denzin \& Lincoln, 2000). Scholars have used this framework to investigate individual experiences regarding feminism (Fisher, 2000), health and illness (Carel, 2016; Svenaeus, 2001), family research therapy (Dahl \& Boss, 2005), religion (Allen, 2005), and education (Brinkman \& Friesen, 2018).

There are three reasons why phenomenology's reliance on everyday knowledge (Garfinkel, 1967), "practical reasoning" (Pollner, 1987), and language and subjectivity, will be particularly useful in this study. For one, this framework validates Dr. Eric Thomas's position as the most appropriate person to articulate his experiences regarding education, prior to and after his work on the doctorate. In other words, phenomenology allows us to understand the mindset [thoughts] Dr. Thomas possessed before earning the doctorate, how that mindset stood in the way of his success, and the specific changes that he made in his life to achieve his goal of earning the doctorate.

Second, this framework honors the emotions [feelings] of Dr. Eric Thomas as he earned this doctorate, specifically his conflicting emotions as he manages his role as student, husband, father, religious leader, and mentor. Hence, through his words, we learn the priorities of Dr. Thomas, how he manages these priorities, as well as his recommendations for work-life balance. Since many students find this balance difficult (Evans et al., 2017; McAlpine et al., 2020; Yusef et al., 2020), the perspective of Dr. Thomas is especially valuable.

Finally, this framework highlights the specific actions [behaviors] Dr. Eric Thomas took as he earned the doctorate. Essentially, phenomenology allows us to place a spotlight on a Black male that did not earn the doctorate in the usual trajectory (i.e., high school to Ph.D.) and the actions that he took to achieve this scholarly distinction. Thus, consistent with the aims of phenomenology, this study will examine the words that Dr. Eric Thomas provides during an interview on the day that he earned his doctorate degree in education from Michigan State University. Essentially, phenomenology allows us to share in the excitement of this academic milestone with Dr. Eric Thomas.

\section{Methodology}

This study used a qualitative approach to examine themes present in Glenn Twiddle's interview with Dr. Eric Thomas on Sunday, May 17, 2015. To determine the themes present, we took several steps. First, the researchers viewed the entire interview as a group. Second, the second author transcribed the first half of the interview and 
the third author transcribed the second half of the interview. Third, to establish the reliability of the transcribed interview, the authors viewed the entire video on four separate dates [Tuesday, June 17, 2020; Tuesday, June 23, 2020; Tuesday, June 30, 2020; Tuesday, July 7, 2020] along with the transcriptions. [See Appendix A-Dr Eric Thomas PH.D.... ET's VERY FIRST Interview After he Graduated!]. On Tuesday, July 28, 2020, the authors met and compared their coded narratives. Because one theme had few supporting statements, the first author decided, with support from the co-authors to add this theme to an existing theme with more qualitative support.

\subsection{Presentation of the Findings}

Qualitative analysis of the interview resulted in the following four themes: (a) The Habit of Avoiding Challenges: (b) The Value of Facing Challenges; (c) The Importance of Receiving Encouragement and Accepting Help; (d) The Fragility of Work-Life Balance.

The "Habit of Avoiding Challenges" theme are words and/or phrases related to the tendency of Dr. Jackson to avoid anything in life that seemed difficult. The "Value of Facing Challenges" theme are words and/or phrases related to the ways that Dr. Jackson felt strong or powerful after confronting trials in life that seemed difficult. In addition, these words and/or phrases relate to the rewards that Dr. Jackson received after facing trials that were difficult as well as the future goal or goals that he set for himself. The "Importance of Receiving Encouragement and Accepting Help" theme are words and/or phrases related to the positive words that Dr. Jackson received from others as well as the specific forms of assistance that he received from others while working on his doctorate degree. The "Fragility of Work-Life Balance" theme are words and/or phrases related to the difficulty of balancing work and family as well as the decisions that Dr. Jackson made to successfully balance work and family. [See Table 1. Qualitative Themes from Dr. Eric Thomas Interview with Glenn Twiddle].

Table 1. Qualitative themes from Dr. Eric Thomas interview with Glenn Twiddle

\begin{tabular}{|c|c|c|}
\hline Theme & Definition of Theme & Support for Theme \\
\hline $\begin{array}{l}\text { The Habit of } \\
\text { Avoiding } \\
\text { Challenges }\end{array}$ & $\begin{array}{l}\text { This theme are words and/or phrases related } \\
\text { to the tendency of Dr. Jackson to avoid } \\
\text { anything in life that seemed difficult. }\end{array}$ & $\begin{array}{l}\text { But I say one thing I feel like um, I can stop running. You know, } \\
\text { I felt like when I was kid (a) when bad stuff would happen I } \\
\text { would just always run. You know, I ran from home when I was } \\
\text { sixteen. You know when I wasn't doing well in college I ran } \\
\text { that's why it took me so long to finish. }\end{array}$ \\
\hline $\begin{array}{l}\text { The Value of } \\
\text { Facing Challenges }\end{array}$ & $\begin{array}{l}\text { This theme are words and/or phrases related } \\
\text { to the ways that Dr. Jackson felt strong or } \\
\text { powerful after confronting trials in life that } \\
\text { seemed difficult. In addition, these words } \\
\text { and/or phrases relate to the rewards that Dr. } \\
\text { Jackson received after facing trials that were } \\
\text { difficult as well as the future goal or goals } \\
\text { that he set for himself. }\end{array}$ & $\begin{array}{l}\text { I feel like I did it. You know what I'm saying what- I } \\
\text { accomplished what I wanted to accomplish in life- I did it and } \\
\text { that was to just finish be a finisher you know to be an executor. }\end{array}$ \\
\hline $\begin{array}{l}\text { The Importance of } \\
\text { Receiving } \\
\text { Encouragement } \\
\text { and Accepting } \\
\text { Help }\end{array}$ & $\begin{array}{l}\text { This theme are words and/or phrases related } \\
\text { to the positive words that Dr. Jackson } \\
\text { received from others as well as the specific } \\
\text { forms of assistance that he received from } \\
\text { others while working on his doctorate degree. }\end{array}$ & $\begin{array}{l}\text { Now, I say I can do this. And it might require the help of others. } \\
\text { You know I may have to network. I may have to be vulnerable } \\
\text { and show I'm weak in some areas. You know I may have to get } \\
\text { people who are stronger in certain areas you to assist me. }\end{array}$ \\
\hline $\begin{array}{l}\text { The Fragility of } \\
\text { Work-Life Balance }\end{array}$ & $\begin{array}{l}\text { This theme are words and/or phrases related } \\
\text { to the difficulty of balancing work and family } \\
\text { as well as the decisions that Dr. Jackson made } \\
\text { to successfully balance work and family. }\end{array}$ & $\begin{array}{l}\text { For four straight days, I'm shutting everybody off and I'm giving } \\
\text { my wife her time. So it's a [it's a] fine line, it is, it's a fine line } \\
\text { but I just believe that if it's important to you, again execution, } \\
\text { you will (claps hands), "ET how am I going to do it..." When } \\
\text { you are great at something, I don't always have the answers for } \\
\text { you, but when it's important (claps hand) to you (claps hands) } \\
\text { you get it done. When it's not important to you, you find an } \\
\text { excuse. }\end{array}$ \\
\hline
\end{tabular}

\section{Discussion}

Using phenomenology, this work determined catalysts that contributed to the educational success of Dr. Eric Thomas. Although this Black male entered academe with a GED, qualitative analysis of his interview revealed four themes related to his current position, namely, (a) The Habit of Avoiding Challenges: (b) The Value of Facing Challenges; (c) The Importance of Receiving Encouragement and Accepting Help; (d) The Fragility of Work-Life Balance.

Before we discuss each of these themes, we would like to mention two limitations of the current work. For one, this interview is one of many public lectures provided by Dr. Thomas. Essentially, this means that while this 
interview is an important milestone in the life of Dr. Thomas, this interview cannot necessarily compare to his subsequent interviews (or lectures) that may not mirror the themes determined herein. In addition, the experiences of Dr. Thomas cannot generalize to other individuals that obtained the doctorate after obtaining the GED. Furthermore, the experiences of Dr. Thomas cannot specifically generalize to other Black males (or females) that obtained the doctorate after obtaining the GED. Despite of these limitations, however, this scholarly work elicits the thoughts, feelings, and behaviors of Dr. Jackson on the day that he officially (and publicly) earned this academic distinction. Thus, because this work allows us to validate the lived experience of Dr. Jackson, especially as it relates to the words that he uses to discuss his educational journey, this work has made a meaningful contribution to the academic literature in regards to educational resilience.

\subsection{The Habit of Avoiding Challenges}

Through his words, we learn that avoiding tasks was a pattern that Dr. Thomas established early in life. Children reared in homes where there is a parental structure tend to do better academically and socially than children that lack this structure (Darensbourg \& Blake, 2014; Farkas \& Grolnick, 2010; Ratelle et al., 2017). It appears that this Black scholar did not have this structure or consciously resisted the confines of a structured home environment. By his own admission, he "left home so early" and at the age of 16 was determined to make decisions that he believed was in his best interest" ("You do what you want to do when you want to do it."). Since he lacked a clear direction for his life, Dr. Thomas established a pattern where he essentially only did what he wanted to do when he wanted to do it. While on the surface this freedom was liberating, it helped create a mindset that any time an insurmountable challenge came, he took the path of least resistance, or avoided that task altogether. Because Dr. Thomas never built a personal reservoir of self-efficacy, or an internal confidence based on past successes through which he overcame, he immediately doubted whether he could successfully overcome any difficulty that came his way. Thus, a habit of not going "to bed on time," not 'getting up and going to school,' placed him on a road where he was running, but never running toward a particular goal. (" $I$ just-it was a habit of just running.").

Dr. Thomas reminds us that not all running is the same. To do this, he used the analogy of a gazelle and a lion to make a clear distinction between two forms of running, namely pursuing and avoiding. He stated, "[The gazelle] is running from something. And the lion is running to something." While both are running, in this context, the lion is the pursuer and the gazelle is the avoider. Dr. Thomas also underscores that running can be protective and advantageous, "I am sure they both (the gazelle and lion) have had some similar success. The fastest gazelle probably has not had to deal with the lion in the way the slowest gazelle [has]." Nonetheless, the gazelle is still avoiding challenges as Dr. Thomas stated, "But, still he is running from something." Nevertheless, Dr. Thomas is still highlighting that running is still avoidance. Additionally, avoidance can delay or impede goal attainment.

Dr. Thomas shared individuals generally become avoidant because they feel overwhelmed. He stated, "[Running] is about this milestone or-or this challenge that is so gigantic that you get overwhelmed. "Additionally, individuals may avoid academic challenges due to the perception of a lack of efficacy, confidence, or competence (Artino, 2012; Batool et al., 2017). Dr. Thomas disclosed initial difficulties with his morale and how a defeatist mentality took hold, "[I used to feel like] I can't do this [this challenge], it is just too much (...) If you ever faced something that just felt so overwhelming and you just [felt] like I just don't have what it takes. So [you say] "I can't, I can't do that" so you just say, "I surrender." Sadly, when this happens, individuals embrace a mindset that eventually becomes a self-fulfilling prophecy. "The self-fulfilling prophecy is, in the beginning, a false definition of the situation evoking a new behavior which makes the originally false conception come true" (Merton, 1948, p. 195). Subsequently, individuals who feel incapable and overwhelmed may engage in avoidant retreating behaviors that catalyze failure and self-defeat. Then, self-sabotaging behaviors and self-fulfilling prophecies may inhibit goal attainment.

Through the words of this Black academician, we understand why it is important that parents tirelessly motivate their children to complete tasks that their children may not find enjoyable or see the inherent value. Parents that create structure in the lives of their children help create individuals who set goals, accomplish those goals, and build self-efficacy (Wood et al., 2015). Furthermore, when these children reach adulthood, they are in a strong position to mentor individuals, who like them at one time, do not see the immediate value of facing challenges head-on (Jackson et al., 2017; Johnson et al., 2020; Latunde \& Clark-Louque, 2016). Furthermore, these adults grow up to be individuals like Dr. Thomas who can empathize with individuals that have a habit of running from challenges. Even more important than empathy, individuals like Dr. Thomas are in the best position to encourage others to set specific goals and actively work toward those goals. Thus, a cycle of running from challenges becomes a cycle of helping self by meeting personal goals and taking joy in the process of encouraging others. Thus, for Dr. Thomas, earning the doctorate was a pinnacle moment in his life because it signaled his transition 
from a runner to "an executor."

\subsection{The Value and Strength of Facing Challenges}

Dr. Thomas utilized various analogies to depict the strength he embodied to face challenges. He did this by proclaiming his transformation from a gazelle to a lion ("Now, it is like I am a lion. I am going to pursuing this thing now. I am not afraid."). In essence, Dr. Thomas transformed from an avoider to a purser. Dr. Thomas noted his approach to challenges is to hunt his goals and conquer his current challenges. Dr. Thomas also utilized the analogy of David and Goliath to portray the strength he displayed to face his challenges (e.g., giants, bullies, and demons). Although David was an accomplished warrior, his statue was much smaller and was not as intimidating as Goliath's statue was (Steussy, 1999). At nine feet and nine inches, the giant Goliath was physically intimidating and had the reputation as "the long-standing bully of the valley" (Lucado, 2006, p. 3). Thus, from outward appearances, it did not seem fathomable that the smaller-statue and less experienced warrior David would be victorious against Goliath. However, through his own determination to defeat his enemy as well as God's strength, David successfully defeated Goliath on the battlefield (Steussy, 1999). Over time, David's victory became synonymous with insignificant individuals successfully overcoming perceived insurmountable challenges based on their sheer will and God's help. In a similar vein, like David, Dr. Thomas refused to run from a seemingly impossible to overcome Goliath-like educational obstacle, faced his fear, and successfully defeated his enemy in battle (obtaining his GED and doctorate). Based on his own words, Dr. Thomas like David felt that he was too insignificant to overcome his goals, but after slaying the giant Goliath became a symbol of overcoming perceived insuperable adversaries and obstacles. Essentially, this David and Goliath analogy reminds individuals that seemingly impossible educational victories can only occur when individuals face Goliath-like fears in life, and thus, open the door to future successes.

Dr. Thomas also noted that individuals could hone strength, tenacity, and endurance via socialization. In this respect, he stated, "For some people, it's easy [facing challenges and achieving goals or accomplishments] just because they started a history of that. I look at my wife and how she makes my kids go to school, make "em graduate. So, they can [get to know] the process of finishing." Hence, parenting and socialization practices can shape goal attainment and emotional regulation (Calkins \& Hill, 2007; Jaramillo et al., 2017). Thus, parents and socializing agents may be able to foster strength through emotional regulation,

Dr. Thomas mentioned various values or benefits from facing his challenges: self-actualization; freedom from escapism and avoidance; interrupting cycles; ability to offer familial and societal contributions; as well as notoriety and respect. Dr. Thomas experienced a sense of self-actualization and accomplishment. Self-actualization means, "Working to do well the things you want to do" (Maslow, 1965, p. 113). As an action, self-actualizing is "an inner focus i.e., differentiation of self, psychological integration or achieving some level of personal potential" (Greene \& Burke, 2007, p. 119). Dr. Thomas expressed this self-actualization via achievements, namely graduating with his $\mathrm{PhD}$. When discussing the joy that he experienced from recognizing his educational potential, he stated, "[Upon graduation and academic achievement], I feel like I did it. You know what I'm saying what-I accomplished what I wanted to accomplish in life- I did it and that was to just finish be a finisher you know to be an executor."

Dr. Thomas also noted he experienced freedom from running and vicious cycles when facing challenges. Upon facing challenges and goal attainments, Dr. Thomas stated he, 'felt like he could stop running.' Hence, by psychologically changing his thinking and then changing his behavior, Dr. Thomas disrupted cycles of failure by turning them into cycles of success. Moreover, this Black academician alluded to how challenges or 'Goliaths' resurface if they are not faced 'head-on'. To make this point clear, he stated, "It might be 5 years down the line [or] now going to 10 years down the line. But, you got to see that thing you run from; you have to face it again." In contrast, when individuals face and slay their challenges or Goliaths they break the cycle. Dr. Thomas conveyed this with the statement: "I will never have to face that giant again because I faced it head-on and you know [I] was able to conquer it."

Dr. Thomas mentioned being able to offer family support because of achieving success. Additionally, Dr. Thomas is able to offer communal and societal contributions, namely mentorship because he 'buckled down' and overcame hardships. Dr. Thomas underscored the significance and benefit of leadership, mentorship, professional and personal development among communities with this statement: 'When you get followers you add but when you get leaders you multiply. And it was kind of like you can either add to people's lives or you can get this Ph.D. and multiply.' This statement highlighted the importance of strong courageous leaders fostering more leaders.

Notoriety and respect are a byproduct of achieving accomplishments amidst adversity. Dr. Thomas used the 
example of Sam Bowie and Michael Jordan to underscore that a person with potential and talent, over time can go unnoticed, if they do not actualize their potential. To this point, Dr. Thomas stated, "Most kids don't know who Sam Bowie is. And they don't know that Sam Bowie got drafted over Michael Jordan," and explained why an individual does not receive recognition. ("But you don't know who Sam Bowie [is] because he did not execute"). However, Michael Jordan obtained fame because of his achievements, a point that Thomas made clear when he stated, "You know Michael Jordan is because he won six NBA titles. He executed." Hence, for Dr. Thomas, recognition is synonymous with execution ("If you don't execute we won't know who you are"). In addition to notoriety, individuals that execute earn respect, "[If] you want people to respect you in your business, they are not going to respect you because you tried because you made an attempt. They are only going to respect you when you get it done."

For context, Bowie was a college basketball star selected over Michael Jordan in the 1984 NBA (National Basketball Association) draft. Winning six NBA Championships and six NBA finals MVP (Most Valuable Player) Awards, Jordan went on to become arguably one of the greatest basketball players of all time, as well as one of the most important athletic figures in sports history. Bowie, on the other hand, did not meet pre-draft expectations and did not have a decorated NBA career like Jordan. Dr. Thomas uses the Bowie and Jordan analogy to express that though Bowie was drafted over Jordan, he did not execute and has essentially become forgotten in sports history. Jordan, on the other hand, is known as a champion and one of the elites in professional sports. Therefore, Dr. Thomas' advice to others is to make a lasting impression in the world by establishing the reputation of being one that executes to the best of one's abilities.

\subsection{The Importance of Receiving Encouragement and Accepting Help}

In addition to being the most marginalized group in education, Black males are more likely to experience higher unemployment, greater incarceration, worse health, and premature death compared to other races and ethnicities (Brown et al., 2013; Dancy II, 2014; Dancy \& Brown, 2012; Howard, 2013; Matthews et al., 2010; Noguera, 2003; Polite \& Davis, 1999). This makes the academic accomplishments of Dr. Thomas even more exceptional. Moreover, Dr. Thomas mentions that his academic achievement did not happen due to his own merit, but through acknowledging that he needed to seek assistance from others.

During his interview, Dr. Thomas expresses his understanding regarding the value of seeking help: "It might require the help of others. You know I may have to network. I may have to be vulnerable and show I'm weak in some areas. You know I may have to get people who are stronger in certain areas to assist me." In essence, Dr. Thomas makes it clear that misdirected machismo is incompatible with help-seeking behavior. Furthermore, he outlined specific thoughts, feelings, and actions that are essential catalysts to success. In particular, Dr. Thomas psychologically accepted that he needed help, was emotionally vulnerable, and earnestly acknowledged the areas in which he was weak. After this exercise in honest self-reflection, Dr. Thomas became conscious that he needed 'to get people who are stronger in certain areas' than he was to assist him. Although he may have initially found this level of help-seeking behavior as a sign of weakness, over time, Dr. Thomas learned that it was ultimately his responsibility to help himself via networking and being open to receiving the help offered to him. Since institutions of higher learning were not initially established to serve the "have nots" (Robinson, 1994), Dr. Thomas was able to effectively navigate the world of academia and benefit from the assistance of others who were capable, able, and willing to bolster his success.

\subsection{The Fragility of Work-Life Balance}

One of the many stressors that doctoral students encounter is managing work-life balance (Martinez et al., 2013). Today, the average doctoral student is a non-traditional student, much like Dr. Thomas (Martinez et al., 2013). The term nontraditional student has been utilized, "to describe students who are older than typical college students, work because of financial necessity, belong to the first generation in their family to attend college, do not live on campus, attend part-time, or are members of minority racial groups (Bers \& Smith, 1987, p. 640). Dr. Eric Thomas fits the description of a nontraditional student. Unlike traditional students, non-traditional students are faced with the task of managing a household, while attempting to successfully matriculate through their graduate studies. Dr. Thomas references the struggles of his academic and non-academic lives, speaking of work-life balance as a fusion between doing equally well in two areas of life. For him, this fusion encompasses the ability to accomplish personal pursuits, as well as to manage family time, or taking care of the family. One of the most profound statements Dr. Thomas made regarding work-life balance was, "...so to me my wife's not my number one, she's my priority." He further explained that in order to complete a task, he had to sacrifice time with his wife and children for several days or even a few months. Dr. Thomas describes this as "cutting people off" in order to reach certain milestones. During this process, he shared that the time that he would normally 
allocate to family and social events, like church, and movies, would have to cease to exist until he reached that milestone. Furthermore, when he says, "I had to sacrifice hoping that if I get it in the end it is going to be better for everybody" and "You have to say this is for my wife or this is for my children or this is for my family. This is for my friends," Dr. Thomas clearly identifies the individuals that are the primary beneficiaries of his sacrifice. In addition, Dr. Thomas makes up for the time sacrificed away from his family by spending an equal amount of time with them. He references scheduling couples' trips for him and his wife, as well as family vacations as ways to balance the time that he allocates toward work.

These accounts from Dr. Thomas demonstrates how he was able to both cope with and manage work-life balance. He manages work-life balance by committing to his studies and sacrificing time with family, but also spending an equal amount of time with family to create a balance. He responds to this method of managing work-life balance by noting that his family and friends will become beneficiaries of his successes. Ultimately, Dr. Thomas has been able to successfully maintain and manage work-life balance through commitment, sacrifice, and having the understanding and support of his family, as they have also had to sacrifice and commit to his academic pursuits.

\section{Conclusion}

During the interview, Dr. Thomas stated "Y'all got next." This remark invites and encourages others to achieve milestones and accomplishments. The phrase "who's got next' has been utilized in various sectors (e.g., sports and music industry) to prompt others to perform and execute achievements. The context in which Dr. Thomas uses "Y'all got next" acts as a verbal affirmation that whatever individuals are dealing with, they can successfully triumph (over obstacles and Goliaths). Also, this statement reminds students and viewers of their position and responsibility to take the world by storm and make a positive difference in the world. In other words, Dr. Thomas is encouraging students and viewers to habitually execute, continually reach personal milestones, and become beacons of academic resilience by overcoming Goliath-like obstacles. This form of encouragement can also apply to any person, regardless of their gender, race, or socioeconomic status. In this sense, the person that has next is one who is willing to sacrifice, seek assistance, successfully manage work-life balance, and execute to ensure that they can achieve personal and professional milestones. Additionally, Dr. Thomas offered insight into how he personally overcame difficulties and achieved milestones. Without question, Dr. Eric Thomas is a remarkable example of academic resilience. During his interview, he was energetic, focused, and unselfishly shared the secrets of success. In particular, he discussed habits that contributed to his past failures as well as the impetus for his current and future educational success. For instance, Dr. Thomas expressed his tendency to avoid challenges (e.g., academic and life challenges). Additionally, Dr. Thomas stressed the significance of facing challenges. The benefits of facing challenges include self-actualization, freedom from escapism, disruption of cycles, societal and familial contributions, and notoriety as well as respect. Furthermore, Dr. Thomas underscored the importance of receiving and embracing encouragement and assistance. Help-seeking behavior, social networking, and social support can be crucial for success especially among ethnic and racial minorities. In addition, Dr. Thomas discussed the significance of managing work-life balance. Regarding work-life balance, Dr. Thomas mentioned sacrificing family and social time; removing interpersonal ties; prioritizing both work and relationships, and; balancing family commitment and academic pursuits.

\section{References}

Adams, J. V. (2019). Success rates of GED credential recipients and high school graduates: A comparative study of Southeast Kentucky Community and Technical College students. Doctoral dissertation, Mississippi State University.

Agasisti, T., Avvisati, F., Borgonovi, F., \& Longobardi, S., (2018). Academic resilience: What schools and countries do to help disadvantaged students succeed in PISA. OECD Education Working Papers, No. 167, OECD Publishing.

Allen, C. R., Angeler, D. G., Chaffin, B. C., Twidwell, D., \& Garmestani, A. (2019). Resilience reconciled. Nature Sustainability, 2(10), 898-900. https://doi.org/10.1038/s41893-019-0401-4

Allen, D. (2005). Phenomenology of religion (pp. 182-207). The Routledge companion to the study of religion.

Allen, W. R. (1992). The color of success: African-American college student outcomes at predominantly White and historically Black public colleges and universities. Harvard Educational Review, 62, 26-44. https://doi.org/10.17763/haer.62.1.wv5627665007v701

Benzies, K., \& Mychasiuk, R. (2009). Fostering family resiliency: A review of the key protective factors. Child 
\& Family Social Work, 14, 103-114. https://doi.org/10.1111/j.1365-2206.2008.00586.x

Bers, T. H., \& Smith, K. (1987). College choice and the nontraditional student. Community College Review, 15(1), 39-45. https://doi.org/10.1177/009155218701500106

Borman, G., \& Overman, L. (2004). Academic resilience in mathematics among poor and minority students. The Elementary School Journal, 104(3), 177-195. https://doi.org/10.1086/499748

Brewer, M. L., van Kessel, G., Sanderson, B., Naumann, F., Lane, M., Reubenson, A., \& Carter, A. (2019). Resilience in higher education students: A scoping review. Higher Education Research \& Development, 38(6), 1105-1120. https://doi.org/10.1080/07294360.2019.1626810

Brinkmann, M., \& Friesen, N. (2018). Phenomenology and education. In International handbook of philosophy of education (pp. 591-608). Springer, Cham. https://doi.org/10.1007/978-3-319-72761-5_46

Brooms, D., \& Davis, A. (2017). Staying focused on the goal: Peer bonding and faculty mentors supporting Black males' persistence in college. Journal of Black Studies, 48(3), 305-326, https://doi.org/10.1177/0021934717692520

Brown, D. L. (2008). African American resiliency: Examining racial socialization and social support as protective factors. Journal of Black Psychology, 34, 32-48. https://doi.org/10.1037/e512292008-001

Brown, M. C., Dancy, T. E., \& Davis, J. E. (2013). Educating African American males: Contexts for consideration, possibilities for practice. Peter Lang.

Bryan, J. (2005). Fostering educational resilience and achievement in urban schools through school-family-community partnerships. Professional School Counseling, 8, 219-227.

Buckner, J. C., Mezzacappa, E., \& Beardslee, W. R. (2003). Characteristics of resilient youths living in poverty: The role of self-regulatory processes. Development and Psychopathology, 15, 139-162. https://doi.org/10.1017/S0954579403000087

Calhoun, Y., Rangel, V. S., \& Coulson, H. L. (2019). Educational resilience at risk? The challenges of attending an early college high school. The Urban Review, 51(2), 301-325. https://doi.org/10.1007/s11256-018-0481-x

Calkins, S., \& Hill, A. (2007). Caregiver influences on emerging emotion regulation. In J. J. Gross (Ed.), Handbook of Emotion Regulation (pp. 229-248). New York, NY: Guilford Press.

Campbell, F. L. (2017). GED Learners' Perceptions of Support Systems for Encouraging High School Completion. Doctoral dissertation, Walden University.

Carel, H. (2016). Phenomenology of illness. Oxford University Press. https://doi.org/10.1093/acprof:oso/9780199669653.001.0001

Carson, D. (2017). The influence of college readiness and institutional intervention upon intention to persist among GED credentialed community college students. Doctoral dissertation, Iowa State University.

Chatterji, M. (2006). Reading achievement gaps, correlates, and moderators of early reading achievement: Evidence from Early Childhood Longitudinal Study (ECLS) kindergarten to first grade sample. Journal of Educational Psychology, 98(1), 489-507. https://doi.org/10.1037/0022-0663.98.3.489

Chen, J., Ziskin, M. B., \& Torres, V. (2020). An analysis of factors affecting dropout risks of nontraditional students: Evidence from US 4-Year commuter institutions. International Journal of Educational Reform, 29(1), 38-59. https://doi.org/10.1177/1056787919874864

Coley, R. J. (2001). Differences in the gender gap: Comparisons across racial/ethnic groups in education and work. Princeton, NJ: Educational Testing Service.

Coley, R. J. (2011). A strong start: Positioning young Black boys for educational success: A statistical profile. Princeton, NJ: Educational Testing Service.

College Board. (2011). The educational experience of young men of color. New York.

Constantine, N., Benard, B., \& Diaz, M. (1999, June). Measuring protective factors and resilience traits in youth: The healthy kids resilience assessment (pp. 3-15). In seventh annual meeting of the Society for Prevention Research, New Orleans, LA.

Cunningham, M., \& Swanson, D. P. (2010). Educational resilience in African American adolescents. The Journal of Negro Education, 473-487. 
Dahl, C. M., \& Boss, P. (2005). The use of phenomenology for family therapy research. Research Methods in Family Therapy, 2, 63-84.

Dancy, T. E., \& Brown, M. C. (2012). African American males and education: Researching the convergence of race and identity. Information Age Publishing.

Darensbourg, A. M., \& Blake, J. J. (2014). Examining the academic achievement of black adolescents: Importance of peer and parental influences. Journal of Black Psychology, 40(2), 191-212. https://doi.org/10.1177/0095798413481384

Davenport, S. (2018). Pipeline to Success (p. 363). Education Doctoral. Retrieved from https://fisherpub.sjfc.edu/education_etd/363

Davis, J. E. (2003). Early schooling and the achievement of African American males. Urban Education, 38(1), 515-537. https://doi.org/10.1177/0042085903256220

Davis, J. E. (2005). Early schooling and academic achievement of African American males. Corwin Press. https://doi.org/10.1177/0042085903256220

Denzin, N. K., \& Lincoln, Y. (2005). The sage handbook of qualitative research. Sage Publications.

Downey, J. A. (2008). Recommendations for fostering educational resilience in the classroom. Preventing School Failure: Alternative Education for Children and Youth, 53(1), 56-64. https://doi.org/10.3200/PSFL.53.1.56-64

Dubois, D. (2003). Effective strategies for esteem-enhancement: What do young adolescents have to say? The Journal of Early Adolescence, 23(4), 405-434. https://doi.org/10.1177/0272431603258346

DuBois, D., Burk-Braxton, C., Swenson, L., Tevendale, H., \& Hardesty, J. (2002). Race and gender influences on adjustment in early adolescence: Investigation of an integrative model. Child Development, 73(5), 1573-1592. https://doi.org/10.1111/1467-8624.00491

Evans, T. M., Bira, L., Beltran - Gastelum, J., Weiss, L. T., \& Vanderford, N. (2017). Mental health crisis in graduate education: The data and intervention strategies. The FASEB Journal, 31, 750-757.

Farkas, M. S., \& Grolnick, W. S. (2010). Examining the components and concomitants of parental structure in the academic domain. Motivation and Emotion, 34(3), 266-279. https://doi.org/10.1007/s11031-010-9176-7

Fergus, E. (2009). Understanding Latino students' schooling experiences: The relevance of skin color among Mexican and Puerto Rican high school students. Teachers College Record, 111(2), 339-375.

Ferguson, A. (2000). Bad boys: Public school in the making of black masculinity. University of Michigan Press. https://doi.org/10.3998/mpub.16801

Fisher, L. (2000). Phenomenology and feminism: Perspectives on their relation. In Feminist phenomenology (pp. 17-38). Springer, Dordrecht. https://doi.org/10.1007/978-94-015-9488-2_2

Ford, C. A. (1996). Factors that Contribute to Academic Resilience among Urban. Challenge: A Journal of Research on African American Men, 7(3), 17-29.

Fry, R. A. (2010). Hispanics, high school dropouts and the GED. Washington, DC: Pew Hispanic Center.

Garfinkel, H. (1967). Studies in ethnomethodology. Prentice Hall.

Garmezy, N. (1991). Resiliency and vulnerability to adverse developmental outcomes associated with poverty. The American Behavioral Scientist, 34, 416-430. https://doi.org/10.1177/0002764291034004003

Greene, L., \& Burke, G. (2007). Beyond self-actualization. Journal of Health and Human Services Administration, 116-128.

Greene, R., \& Conrad, A. (2002). Basic assumptions and terms. In R. Greene (Ed.), Resiliency: An integrated approach to practice, policy, and research (pp. 29-62). NASW Press.

Grover, S. D. (2013). Exploring General Education Development Retention. Doctoral dissertation, Walden University.

Heckman, J. J., Humphries, J. E., LaFontaine, P. A., \& Rodriguez, P. L. (2012). Taking the easy way out: How the GED testing program induces students to drop out. Journal of Labor Economics, 30(3), 495. https://doi.org/10.1086/664924

Heckman, J. J., Humphries, J. E., \& Mader, N. S. (2011). The ged. In Handbook of the Economics of Education (Vol. 3, pp. 423-483). Elsevier. https://doi.org/10.1016/B978-0-444-53429-3.00009-0 
Howard, T. C. (2013). How does it feel to be a problem? Black male students, schools, and learning in enhancing the knowledge base to disrupt deficit frameworks. Review of Research in Education, 37(1), 54-86. https://doi.org/10.3102/0091732X12462985

Jackson, I., Sealey-Ruiz, Y., \& Watson, W. (2014). Reciprocal love: Mentoring Black and Latino males through an ethos of care. Urban Education, 49(4), 394-417. https://doi.org/10.1177/0042085913519336

Jaggers, D., \& Iverson, S. V. (2012). “Are you as hard as 50 Cent?" Negotiating race and masculinity in the residence halls. Journal of College and University Student Housing, 39(1), 186-199.

Jaramillo, J. M., Rendón, M. I., Muñoz, L., Weis, M., \& Trommsdorff, G. (2017). Children's self-regulation in cultural contexts: The role of parental socialization theories, goals, and practices. Frontiers in Psychology, 8 , 923. https://doi.org/10.3389/fpsyg.2017.00923

Joe, E. M., \& Davis, J. E. (2010). Parental influence, school readiness and early academic achievement of African American boys. The Journal of Negro Education, 78(3), 260-276. http://www.jstor.com/stable/25608745

Johnson, M. W., Brown, A. L., \& Harrison, L. (2020). Troubling the waters: A critical essay on Black male role models and mentors. The Urban Review, 52(3), 415-434. https://doi.org/10.1007/s11256-019-00538-x

Justice, L. M., Invernizzi, M. A., Geller, K., Sullivan, A., \& Welsch, J. (2005). Descriptive-developmental performance of at-risk preschoolers evaluating learning-related skills on early literacy tasks: Associations with age, race, and gender. Reading Psychology, 26(1), 1-25. https://doi.org/10.1080/02702710490897509

Kafele, B. K. (2012). Empowering young Black males. Educational Leadership, 70(2), 67-70.

Kim, E., \& Hargrove, D. T. (2013). Deficient or resilient: A critical review of Black male academic success and persistence in higher education. The Journal of Negro Education, 82(3), 300-311. https://doi.org/10.7709/jnegroeducation.82.3.0300

Larson, K., Gaeta, C., \& Sager, L. (2016). GED Test Changes and Attainment: Overview of 2014 GED Test Changes and Attainment in Washington State. Washington Student Achievement Council.

Latunde, Y., \& Clark-Louque, A. (2016). Untapped resources: Black parent engagement that contributes to learning. The Journal of Negro Education, 85(1), 72-81. https://doi.org/10.7709/jnegroeducation.85.1.0072

Lee, J. (2002). Racial and ethnic achievement gap trends: Reversing the progress toward equity? Educational Researcher, 31(1), 3-12. https://doi.org/10.3102/0013189X031001003

Legters, N. E., Balfanz, R., Jordan, W. J., \& McPartland, J. M. (2004). Comprehensive reform for urban high schools. Thomson Wadsworth.

Liu, J. J., Reed, M., \& Girard, T. A. (2017). Advancing resilience: An integrative, multi-system model of resilience. Personality and Individual Differences, 111, 111-118. https://doi.org/10.1016/j.paid.2017.02.007

Losen, D. J., Keith II, M. A., Hodson, C. L., \& Martinez, T. E. (1972). School Discipline. The Center for Civil Rights Liberties.

Lucado, M. (2006). Facing Your Giants: A David and Goliath Story for Everyday People. Thomas Nelson Inc.

Luthar, S. S. (2006). Resilience in development: A synthesis of research across five decades. In D. Cicchetti \& D. J. Cohen (Eds.), Developmental psychopathology: Risk, disorder, and adaptation (pp. 739-785). Wiley. https://doi.org/10.1002/9780470939406.ch20

Luthar, S. S., Cicchetti, D., \& Becker, B. (2000). The construct of resilience: A critical evaluation and guidelines for future work. Child Development, 71, 543-562. https://doi.org/10.1111/1467-8624.00164

Maralani, V. (2011). From GED to college: Age trajectories of nontraditional educational paths. American Educational Research Journal, 48(5), 1058-1090. https://doi.org/10.3102/0002831211405836

Marcucci, O. (2020). Implicit bias in the era of social desirability: Understanding antiblackness in rehabilitative and punitive school discipline. The Urban Review, 52(1), 47-74. https://doi.org/10.1007/s11256-019-00512-7

Martin, A. J., \& Marsh, H. W. (2006). Academic resilience and its psychological and educational correlates: A construct validity approach. Psychology in the Schools, 43(3), 267-281. https://doi.org/10.1002/pits.20149

Martinez, E., Ordu, C., Della Sala, M.R., McFarlane, A. (2013). Striving to obtain a school-work-life balance: 
The full-time doctoral student. International Journal of Doctoral Studies, 8(1), 39-59. https://doi.org/10.28945/1765

Maslow, A. (1965). Self-actualization and beyond [microform]. Distributed by ERIC Clearinghouse.

Masten, A. S. (2006). Developmental psychopathology: Pathways to the future. International Journal of Behavioral Development, 30, 47-54. https://doi.org/10.1177/0165025406059974

Masten, A. S. (2016). Resilience in the context of ambiguous loss: A commentary. Journal of Family Theory \& Review, 8(3), 287-293. https://doi.org/10.1111/jftr.12154

Masten, A. S., Gewirtz, A. H., \& Sapienza, J. K. (2013, October). Resilience in Development: The importance of early childhood. Encyclopedia on Early Childhood Development. Retrieved from http://www.childencyclopedia.com/resilience/according-experts/resilience-development-importance-early-c hildhood

Masten, A. S., \& Reed, M.-G. J. (2002). Resilence in development. In C. R. Snyder \& S. J. Lopez (Eds.), Handbook of positive psychology (pp. 74-88). Oxford University Press.

Matthews, J., Cortina, K., \& Rowley, S. (2010). African Americans and boys: Understanding the literacy gap, tracing academic trajectories, and evaluating the role of learning-related skills. Journal of Educational Psychology, 102(3), 757-771. https://doi.org/10.1037/a0019616

McAlpine, L., Skakni, I., \& Pyhältö, K. (2020). PhD experience (and progress) is more than work: Life-work relations and reducing exhaustion (and cynicism). Studies in Higher Education, 1-15. https://doi.org/10.1080/03075079.2020.1744128

McIntosh, A. S. (2002). Categorization: Impact on African American learners with exceptionalities. Corwin Press.

McMillan, J. H., \& Reed, D. F. (1994). At-risk students and resiliency: Factors contributing to academic success. The Clearing House, 67(3), 137-140. https://doi.org/10.1080/00098655.1994.9956043

Meiners, E. R., \& Winn, M. T. (2010). Resisting the school to prison pipeline: The practice to build abolition democracies. Race Ethnicity and Education, 271-276. https://doi.org/10.1080/13613324.2010.500832

Merton, R. K. (1948). The self-fulfilling prophecy. The Antioch Review, 8(2), $193-210$. https://doi.org/10.2307/4609267

Miles, A. D. (2020). A comparison of the success of community college graduates who entered college with a GED, a high school diploma, or an alternative diploma. Doctoral dissertation, Mississippi State University.

Morales, E. E., \& Trotman, F. K. (2004). Promoting academic resilience in multicultural America: Factors affecting student success (Vol. 29). Peter Lang.

Morales, E. E., \& Trotman, F. K. (2011). A focus on hope: Fifty resilient students speak. University Press of America.

Moran, D. (2002). Introduction to phenomenology. Routledge. https://doi.org/10.4324/9780203196632

Morrison, G. M., \& Allen, M. R. (2007). Promoting student resilience in school contexts. Theory into Practice, 46(2), 162-169. https://doi.org/10.1080/00405840701233172

Murray, C., \& Malmgren, K. (2005). Implementing a teacher-student relationship program in a high-poverty urban school: Effects on social, emotional, and academic adjustment and lessons learned. Journal of School Psychology, 43(2), 137-152. https://doi.org/10.1016/j.jsp.2005.01.003

Murray, N. L. (2018). Examining academic resilience factors among African American high school students [ProQuest Information \& Learning]. In Dissertation Abstracts International (Section A: Humanities and Social Sciences, p. 79).

Nance, J. P. (2015). Over-disciplining students, racial bias, and the school-to-prison pipeline. U. Rich. L. Rev., 50, 1063-1074.

Neitzel, J. (2018). Research to practice: Understanding the role of implicit bias in early childhood disciplinary practices. Journal of Early Childhood Teacher Education, 39(3), $232-242$. https://doi.org/10.1080/10901027.2018.1463322

Newman, J. L., \& Dantzler, J. (2015). Fostering individual and school resilience: When students are at risk move 
from receivers to givers. Journal of Community Engagement and Scholarship, 8(1), 80-89.

Noguera, P. (2003). The trouble with black boys and other reflections on race, equity, and the future of public education. Wiley \& Sons.

Noguera, P. A. (2003). The trouble with Black boys: The role and influence of environmental and cultural factors on the academic performance of African American males. Urban Education, 38(1), 431-459. https://doi.org/10.1177/0042085903038004005

Okonofua, J. A., \& Eberhardt, J. L. (2015). Two strikes: Race and the disciplining of young students. Psychological Science, 26, 617-624. https://doi.org/10.1177/0956797615570365

Olsson, C. A., Bond, L., Burns, J. M., Vella-Brodrick, D. A., \& Sawyer, S. M. (2003). Adolescent resilience: A concept analysis. Journal of Adolescence, 26, 1-11. https://doi.org/10.1016/S0140-1971(02)00118-5

Polite, V. C., \& Davis, J. E. (1999). African American males in school and society: Practices and policies for effective education. Teachers College Press.

Pollner, M. (1987). Mundane reason: Reality in everyday and sociological discourse. Cambridge University Press.

Quinn, L. M. (2002). An institutional history of the GED. ETI Publications. 112. Retrieved from https://dc.uwm.edu/eti_pubs/112

Rak, C. F., \& Patterson, L. E. (1996). Promoting resilience in at-risk children. Journal of Counseling \& Development, 74, 368-373. https://doi.org/10.1002/j.1556-6676.1996.tb01881.x

Ratelle, C. F., Duchesne, S., \& Guay, F. (2017). Predicting school adjustment from multiple perspectives on parental behaviors. Journal of Adolescence, 54, 60-72.

Reardon, S. F. (2006). Invited commentary: Examining patterns of development in early elementary school using ECLS-K data. Education Statistics Quarterly, 6(1). Retrieved from http://nces.ed.gov/programs/quarterly/vol_6/6_3/2_2.asp

Rendon, L. I. (1994). Validating culturally diverse students: Toward a new model of learning and student development. Innovative Higher Education, 19(1), 33-51. https://doi.org/10.1007/BF01191156

Rice, K. M. (2019). Improving the General Education Development (GED): Retention and Completion Rates of Low Income Adults. Doctoral dissertation, Walden University.

Robertson, I. (2018). Personal resilience. Community Practitioner, 90(12), 48-49.

Ruiz, Y. (2002). Predictors of academic resiliency for Latino middle school students. Doctoral dissertation, ProQuest Information \& Learning.

Rutter, M. (1987). Psychosocial resilience and protective mechanisms. The American Journal of Orthopsychiatry, 57, 316-331. https://doi.org/10.1111/j.1939-0025.1987.tb03541.x

Rutter, M. (2007). Resilience, competence and coping. Child Abuse and Neglect, 31, $205-209$. https://doi.org/10.1016/j.chiabu.2007.02.001

Schott Foundation for Public Education. (2012a). The urgency of now: The Schott 50 State Report on Public Education and Black Males. Retrieved from http://www.blackboysreport.org

Schott Foundation for Public Education. (2012b). A rotting apple: Education redlining in New York City. Retrieved from http://schottfoundation.org/resources/education-redlining-new-york-city

Scott, A., Taylor, K., \& Palmer, R. (2013). Challenges to success in higher education: An examination of educational challenges from the voices of college-bound Black males. The Journal of Negro Education, 82(3), 288-299. https://www.jstor.org/stable/10.7709/jnegroeducation.82.3.0288

Silverman, I. W. (2003). Gender differences in resistance to temptation: Theories and evidence. Developmental Review, 23(1), 219-259. https://doi.org/10.1016/S0273-2297(03)00012-1

Smith, D. W. (2006). Phenomenology. Encyclopedia of Cognitive Science. https://doi.org/10.1002/0470018860.s00153

Steussy, M. J. (1999). David: Biblical Portraits of Power. Univ. of South Carolina Press.

Strayhorn, T. L. (2010). When race and gender collide: Social and cultural capital's influence on the academic achievement of African American and Latino males. The Review of Higher Education, 33(3), 307-332. https://doi.org/10.1353/rhe.0.0147 
Svenaeus, F. (2001). The phenomenology of health and illness. In Handbook of phenomenology and medicine (pp. 87-108). Springer, Dordrecht. https://doi.org/10.1007/978-94-010-0536-4_5

Thapa, A., Cohen, J., Guffey, S., \& Higgins-D'Alessandro, A. (2013). A review of school climate research. Review of Educational Research, 83(3), 357-385. https://doi.org/10.3102/0034654313483907

Thompson, G. L., Warren, S., \& Carter, L. (2004). It's not my fault: Predicting high school teachers who blame parents and students for students' low achievement. High School Journal, 87, 5-14. https://doi.org/10.1353/hsj.2004.0005

Trask-Tate, A., \& Cunningham, M. (2010). Planning ahead: The relationship among school support, parental involvement, and future academic expectations in African American adolescents. Journal of Negro Education, 79(2), 137-150.

Twiddle, G. (May 17, 2015). Dr Eric Thomas PH.D....ET's VERY FIRST Interview After he Graduated! Retrieved from https://www.youtube.com/watch?v=F1R9Z2fvO24

Tyler, J. H. (2005). The general educational development (GED) credential: History, current research, and directions for policy and practice. Review of Adult Learning and Literacy, 5, 45-84.

Ungar, M. (2008). Resilience across cultures. British Journal of Social Work, 38, 218-235. https://doi.org/10.1093/bjsw/bcl343

Walberg, H. J., Reyes, O., \& Weissberg, R. P. (Eds.) (1997). Children and youth: Interdisciplinary perspectives (pp. 119-140). Sage.

Wang, M. C., \& Gordon, E. W. (Eds.). (1994). Educational resilience in inner-city America: Challenges and prospects (pp. 45-72). L. Erlbaum Associates.

Wang, M. C., Haertel, G. D., \& Walberg, H. J. (1997a). Fostering educational resilience in inner-city schools. Children and Youth, 7(4), 119-140.

Wang, M. C., Haertel, G. D., \& Walberg, H. J. (1997b). Toward a knowledge base for school learning. Review of Educational Research, 63, 249-294. https://doi.org/10.3102/00346543063003249

Warren, J. R., Jenkins, K. N., \& Kulick, R. B. (2006). High school exit examinations and state-level completion and GED rates, 1975 through 2002. Educational Evaluation and Policy Analysis, 28(2), 131-152. https://doi.org/10.3102/01623737028002131

Waxman, H. C., Gray, J. P., \& Padron, Y. N. (2003). Review of research on educational resilience.

Waxman, H. C., Huang, S. L., \& Padron, Y. N. (1997). Motivation and learning environment differences between resilient and non-resilient Latino middle school students. Hispanic Journal of Behavioral Sciences, 19, 137-155. https://doi.org/10.1177/07399863970192003

Werner, E. (2012). Risk, resilience, and recovery. Reclaiming Children and Youth, 21(1), 18-23.

Werner, E. E. (1993). Risk, resilience, and recovery: Perspectives from the Kauai longitudinal study. Development and Psychopathology, 5, 503-515. https://doi.org/10.1017/S095457940000612X

Williams, J. M., \& Portman, T. A. (2014). “No one ever asked me”: Urban African American students' perceptions of educational resilience. Multicultural Counseling and Development, 42(1), 13-30. https://doi.org/10.1002/j.2161-1912.2014.00041.x

Winn, M. T. (2019). Girl time: Literacy, justice, and the school-to-prison pipeline. Teachers College Press.

Wood, J. L., Newman, C. B., \& Harris III, F. R. A. N. K. (2015). Self-Efficacy as a Determinant of Academic Integration: An Examination of First-Year Black Males in the Community College. Western Journal of Black Studies, 39(1), 3-17.

Yusuf, J. E., Saitgalina, M., \& Chapman, D. W. (2020). Work-life balance and well-being of graduate students. Journal of Public Affairs Education, 1-26. https://doi.org/10.1080/15236803.2020.1771990

Zolkoski, S. M., Bullock, L. M., \& Gable, R. A. (2016). Factors associated with student resilience: Perspectives of graduates of alternative education programs. Preventing School Failure: Alternative Education for Children and Youth, 60(3), 231-243. https://doi.org/10.1080/1045988X.2015.1101677

\section{Notes}

Note 1. Passed in 1944 with the signature of President Franklin Roosevelt, the GI "Bill of Rights" provided 
various benefits to World War II and subsequent veterans, including funds for postsecondary education. In the peak year of 1947, veterans accounted for $49 \%$ of the total college enrollment in the United States (http://www.gibill.va.gov/education/ GI_Bill.htm).

Note 2. There were approximately 1.6 million 12th graders in 1949 (National Center for Education Statistics, 1993).

\section{Copyrights}

Copyright for this article is retained by the author, with first publication rights granted to the journal.

This is an open-access article distributed under the terms and conditions of the Creative Commons Attribution license (http://creativecommons.org/licenses/by/4.0/). 